\title{
Does Institutional Type Affect Alumnae Donating Patterns in the United States?
}

Received (in revised form) Feburary 24, 2003

\section{Peter Briechle}

Peter Briechle is the acting Assistant Director of Research and Data Support in the department of Alumni Affairs and Development at Cornell University. He received a Ph.D. in Higher Education Leadership and Policy and also holds degrees in Economics and Business Management from the State University of New York at Buffalo, a member of the Association of American Universities. His main areas of interest focus on fundraising research, university/business alliances and access to higher education.

\begin{abstract}
Women currently comprise over 55

percent of college and university enrollments and control a substantial amount of wealth in the United States. Yet historical research on philanthropy has made little distinction between male and female donors. Are there no differences or have we failed to understand why women give? This study investigated the effect of institutional type (public, private sectarian, or private nonsectarian) on alumnae donating patterns. An anonymous mail survey was used to gather data on the factors that persuaded alumnae to donate to their alma mater and the areas they gave financial support. The results indicate associations between institution type and six of 12 factors that persuaded alumnae
\end{abstract}

\footnotetext{
Author's Contact Address:

Dr. Peter Briechle

Assistant Director, Alumni Affairs \& Development

Cornell University

55 Brown Road

Ithaca, NY 14850, USA

Phone: +1607 2551842

Email: pb95@cornell.edu
}

to donate and seven of 11 areas they supported financially.

\section{Keywords: \\ philantbropy, fund raising, higher education finance, alumnae, women, donor, donating, giving}

\section{Introduction}

Since the early 1990s, scholars have increasingly studied women as a potential source of philanthropic giving.

Traditionally they have been perceived as a source of volunteers who gave their time, but not necessarily their money. Older women are especially likely to be viewed this way, since many have never had a career and are often hesitant to contribute what they perceive as their husbands' hard-earned money. ${ }^{1}$ This traditional view has changed in the recent past.

As the enrollment of women in institutions of higher education has increased, and surpassed that of men, their influence on American society has evolved. ${ }^{2}$ These "career women" have become more financially independent, thereby relying less on men and husbands for economic 
support. "The average income of working women is increasing at a far greater pace than that of men, according to the U.S. Census Bureau, and two-thirds of all jobs created in the 1990s are expected to be filled by women."3 And the fact that, on average, women outlive men by approximately seven years should alert fund-raising professionals to the opportunities at hand. This economic evolution creates an opportunity for fundraising professionals to elicit financial support from women in an effort to advance the mission of their specific institution.

\section{Problem Statement}

Fund raising in higher education will become even more important in the future. This is due to a variety of reasons, including the decreased financial support of public institutions of higher education by state governments, reductions in financial aid that are making college unaffordable to a growing segment of the middle class, and increased competition to retain and attract the best faculty. The competition for faculty is not only coming from other universities but also from the private sector, which is able to offer lucrative salaries as well as offering bonuses and stock options.

Since women donors are now an important component of any school's successful fund-raising campaign, more research must be conducted to verify and validate previous findings and make new discoveries. By understanding the factors that persuade women to donate based on institutional type, fund raisers can manage campaigns more effectively and efficiently.

\section{Purpose of the Study}

The purpose of this study was to gain information about women's donating patterns and to discover what persuades them to donate based on institution type (public, private sectarian, private nonsectarian). It may allow fund-raising marketing efforts to become more focused and institution-specific, thereby reducing costs. Factors that persuade a woman to donate to her public university may be completely different from factors that persuade a woman who graduated from a private college. This would allow fundraising professionals to gear their marketing plan to a specific niche and possibly increase the yield of women donors.

\section{Research Questions}

The following research questions compare alumnae across institutional type (public, private sectarian, and private nonsectarian). The research questions are (1) are there differences, among institutions studied, in the factors that persuade alumnae to donate to their alma mater and (2) are there differences in the programs that women are most likely to support?

\section{Literature Review}

Sondra Shaw and Martha Taylor (1995)

have conducted extensive research on women as philanthropists. They point out that women and men give for different reasons. Within higher education, men predominantly give because they feel loyalty to their alma mater. Knowing how much a classmate or fraternity brother contributed may heighten a man's competitive nature. Public recognition for donations also seems more important to men than to women. Women view public recognition as unimportant, which can cause frustration for fund raisers, since the positive contributions of women's giving 
are not influential to other potential women philanthropists. ${ }^{4}$

The University of California at Los Angeles (UCLA) Women and Philanthropy Program attempts to involve women in the UCLA community through involvement, education, support, and leadership. Many important themes have emerged; one was the sense that philanthropy was a responsibility and a family tradition beginning at home. "In some homes philanthropy was consciously taught; in others the children learned by example." Church and youth group affiliations were also a strong influence. These women supported the organizations' causes through the donation of time and money. Although not all were able to donate time, those who did "wanted to serve as role models, to give back to others, to make new friends, to increase their self-esteem, and to give of themselves." In this way philanthropy was passed on from generation to generation. Some women also felt a need to repay, since they at one time were the recipient of a gift.

Rosalie M. Simari’s (1995) dissertation entitled "Philanthropy and higher education: Women as donors" examined the factors that may influence women's decisions to support their college or university financially. Her study examined women donors and nondonors who earned an undergraduate degree from a single private nonsectarian institution. She found that a desire "to help the next generation of students and a loyalty to the university were the strongest reasons for providing financial support." ${ }^{\text {" The }}$ Thea that received the strongest financial support was student scholarships, awards, and loans. Bressi (1999) found similar results at a large, public, land grant institution in the southeastern United States. ${ }^{9}$ Fisher et al. (2000) also found "the most popular reported restricted gifts were scholarships" for alumnae of coeducational institutions included in the study. ${ }^{10}$

Although more research on women donors has recently been conducted, there is a need to continue to validate and refine this area of study. ${ }^{11}$ Most studies within the realm of higher education have been institution-specific. This study compares women across institutional type to determine if differences exist. Since fund raising in higher education will gain greater importance, any information that will assist fund-raising professionals to become more efficient and effective in their fund-raising campaigns will be beneficial.

\section{Methodology}

The research questions for this study compared women's responses across three different types of institutions. The independent variable was institution type (public, private nonsectarian, and private sectarian) and the dependent variables were (a) factors that persuade women to donate and (b) programs to which they gave financial support.

The three participating institutions were all located in New York State. The public university and the private nonsectarian university are both Research I (Carnegie Classification) universities. The private sectarian institution is a four-year liberal arts college founded by the Free Methodist Church of North America. Women who met the following criteria were potential subjects in the study: (1) alumnae of institution, (2) have donated at least $\$ 500$ as a single gift in the past five years (199599), and (3) currently reside in the United 
States. The second criterion was important to fund raisers since the donor who made such a gift probably gave it considerable thought, as opposed to someone making a "token" gift. For the purpose of this study the three institutions will be referred to as public (public university), private (private nonsectarian university), and sectarian (private sectarian college).

Both the independent variable and the dependent variables are categorical in nature, therefore Chi-square $\left(\chi^{2}\right)$ tests of association were used to analyze the data with a significance level $(\alpha)$ of 0.05 . The Statistical Package for the Social Sciences (SPSS) was used to analyze the data.

Since Simari's survey was well developed and permission was granted by the author to use the survey at other universities, it was decided to incorporate a number of themes, with modified questions, into this survey. ${ }^{12}$ The Dillman approach to mail surveys was used, resulting in a 73.5 percent response rate. ${ }^{13}$

\section{Results}

\section{Factors persuading women to donate} The first research question was: are there differences in the factors that persuade alumnae to donate to their alma mater among institutions studied? Subjects were asked to choose the top three reasons for donating from a list of 12 possible choices. Table 1 lists the choices by institution. The public and private institutions share the same top three choices, although not in the same order. The sectarian institution shares two of the three choices with the public and private; however, the third choice differs. There are associations between the institution type and six of the twelve factors that persuade women to give, which are described below.

\section{Sense of obligation to institution}

Sense of obligation to the institution was the first choice of the public alumnae, the second choice of the private alumnae, and

Table 1: Factors that persuade women to donate $(N=536)$

\begin{tabular}{lllr}
\hline & \multicolumn{3}{c}{ Institution } \\
\cline { 2 - 4 } & $\begin{array}{l}\text { Public } \\
(N=203)\end{array}$ & $\begin{array}{l}\text { Private } \\
(N=254)\end{array}$ & $\begin{array}{l}\text { Sectarian } \\
(N=79)\end{array}$ \\
\hline Sense of obligation (\%) & 61.6 & 59.1 & 27.8 \\
Positive impact (\%) & 53.7 & 54.3 & 50.6 \\
Loyalty to institution (\%) & 51.7 & 65.0 & 73.4 \\
Knowledge of institutional mission (\%) & 33.5 & 33.1 & 84.8 \\
Tax benefits (\%) & 21.7 & 22.8 & 10.1 \\
Person asking for gift (\%) & 16.3 & 8.7 & 7.6 \\
Involvement in sponsored events (\%) & 13.3 & 9.4 & 10.1 \\
Fund raising literature (\%) & 4.9 & 8.7 & 5.1 \\
Public recognition (\%) & 4.4 & 1.2 & 1.3 \\
Capital campaign under way (\%) & 3.9 & 7.1 & 21.5 \\
Gift level of others (\%) & 2.5 & 2.8 & 0.0 \\
Other (\%) & 13.3 & 15.0 & 5.1 \\
\hline
\end{tabular}

Note: Percentages do not equal $100 \%$ because subjects chose their top three choices 
the fourth choice of sectarian alumnae. There is an association between this factor and institutional type, $\chi^{2}(2, N=536)=$ 28.780, $p<0.05$. Alumnae from the public and private were more than twice as likely to choose "sense of obligation" as a reason to give than were alumnae from the sectarian institution.

\section{Loyalty to institution}

Loyalty to the institution was the first choice of the private alumnae, second most popular choice of the sectarian alumnae, and third most popular choice of public alumnae. There was an association between this factor and institutional type, $\chi^{2}(2, N=536)=14.154$, $p<0.05$. Although it was in the top three choices of all alumnae, the sectarian and private alumnae were more likely to choose "loyalty to the institution" as a reason to give than were the public alumnae. Nearly three-quarters of the sectarian alumnae and nearly two-thirds of the private alumnae made this choice. Slightly more than one-half of the public alumnae did the same.

\section{Knowledge of institutional mission}

Knowledge of institutional mission was the most frequent choice of the sectarian alumnae, with a significant association between this particular factor and institution type, $\chi^{2}(2, N=536)=74.081$, $p<0.05$. Alumnae of the sectarian institution were more than two-and-a-half times as likely to have chosen "knowledge of institutional mission" as a reason to give than were alumnae from both the public and private institution. Nearly 85 percent of sectarian alumnae made this a top three choice, whereas the public and private alumnae selected this choice only one-third of the time.

\section{Tax benefits}

Although benefiting from federal and/or state tax deductions was not chosen by a majority of alumnae, women from the public and private institution were twice as likely to be persuaded by this choice than the sectarian alumnae. There was an association between this variable and institutional type, $\chi^{2}(2, N=536)=6.232$, $p<0.05$.

\section{Person asking for the gift}

The person asking for a gift was nearly twice as important to the public alumnae compared with women at the private or sectarian institutions. Although this choice was not altogether popular, an association between this variable and institutional type did exist, $\chi^{2}(2, N=536)=7.769$, $p<0.05$.

\section{Knowing that a capital campaign is under way}

Knowing that a capital campaign was under way was much more important to the sectarian alumnae than to either the public or private alumnae. In fact, the sectarian alumnae chose this factor five times more often than the public alumnae and three times more often than the private alumnae. Although this choice was not among the top three, an association between this variable and institutional type did exist, $\chi^{2}(2, N=536)=24.387, p<0.05$.

The factor "making a positive impact with a gift" was chosen at least half the time by alumnae of all institutions. Although there was no association with this variable and institutional type, fund raisers must be aware that this factor is important to alumnae when developing marketing campaigns. All other variables showed no association with institutional type. 
Table 2: Areas alumnae support financially $(N=528)$

\begin{tabular}{llll}
\hline & \multicolumn{3}{c}{ Institution } \\
\cline { 2 - 4 } Area & $\begin{array}{l}\text { Public } \\
(N=199)\end{array}$ & $\begin{array}{l}\text { Private } \\
(N=250)\end{array}$ & $\begin{array}{l}\text { Sectarian } \\
(N=79)\end{array}$ \\
\hline Scholarships, awards, and loans (\%) & 69.8 & 81.6 & 69.6 \\
Specific school or department (\%) & 67.3 & 40.8 & 21.5 \\
General fund (\%) & 45.7 & 62.8 & 86.1 \\
Library (\%) & 21.1 & 24.0 & 7.6 \\
Endowed faculty/chair (\%) & 18.1 & 16.8 & 5.1 \\
Endowment (\%) & 14.6 & 20.9 & 32.9 \\
Technology (\%) & 12.1 & 7.2 & 5.1 \\
Renovations/new buildings (\%) & 7.0 & 13.2 & 49.4 \\
Women's athletics (\%) & 6.0 & 6.4 & 1.3 \\
All athletics (\%) & 2.5 & 1.2 & 3.8 \\
Other support (\%) & 7.5 & 8.0 & 6.3 \\
\hline
\end{tabular}

Note: Percentages do not equal 100\% because subjects chose their top three choices

\section{Funding choices}

The second research question asked alumnae to select the top three funding choices from a list of 11 areas as displayed in Table 2. Of the 11 areas, seven were found to have an association by institution.

\section{Scholarships, awards, and loans}

Scholarships, awards, and loans were the first choice of the private and public alumnae and the second choice of the sectarian alumnae. There was an association between this variable and institutional type, $\chi^{2}(2, N=528)=9.904$, $p<0.05$. Although "scholarships, awards and loans" was ranked in the top three of all institutions, the private alumnae were most likely to give financial support in this area.

\section{Specific school or department}

A specific school or department was the second most popular choice of the public alumnae, and the third most popular choice of private alumnae. However, only 21.5 percent of the sectarian alumnae made this choice. There was an association between this variable and institutional type, $\chi^{2}(2, N=527)=57.204, p<0.05$. Alumnae of the public institution were three times more likely to give financial support to a specific school or department than the sectarian alumnae and one and a half times more likely than the private alumnae.

\section{General fund}

The general fund was the most frequent choice of the sectarian alumnae, the second most frequent choice of the private alumnae, and the third most frequent choice of the public alumnae. Although this area was in the top three choices of all institutions, an association between this variable and institutional type did exist, $\chi^{2}(2, N=528)=40.031, p<0.05$. The sectarian alumnae were nearly twice as likely to give financial support to the general fund, as were the public alumnae. 


\section{Library}

Financial support of the library system was not in the top three choices of any institution; however, an association between this variable and institutional type did exist, $\chi^{2}(2, N=528)=10.013$, $p<0.05$. The private and public alumnae were approximately three times as likely to support the library financially than were the sectarian alumnae.

\section{Endowed faculty professors and chairs} Although endowed faculty professors and chairs were not in the top three choices of any institution, an association between this variable and institutional type did exist, $\chi^{2}(2, N=528)=7.899, p<0.05$. The public and private alumnae were more than three times as likely to support endowed faculty professors and chairs financially than were the sectarian alumnae.

\section{Endowment}

The endowment was not among the top three choices of any institution; however there was an association between this variable and institutional type, $\chi^{2}(2$, $N=527)=11.851, p<0.05$. The sectarian alumnae were much more likely to support the endowment as compared with the public and private alumnae. In fact, the sectarian alumnae were more than twice as likely as the public alumnae and one and a half times as likely as the private alumnae to support this area.

\section{Renovations and new buildings}

Renovations and new buildings was the third most popular choice of the sectarian alumnae, but ranked much lower at the public and private institutions. An association between this variable and institutional type did exist, $\chi^{2}(2, N=528)$
$=77.643, p<0.05$. The sectarian alumnae were seven times more likely to support this area than the public and nearly four times more likely than the private alumnae.

All other areas of financial supportwomen's athletics, all athletics, technology, and other support-showed no association with institutional type.

\section{Significance to Practitioners}

The most important implication of this study, for the practitioner, is to realize that differences in alumnae giving may exist at their college or university based on institutional type. Referring to Table 1, the first four factors that persuaded women to donate were chosen most often by all alumnae. However, the degree of importance of each factor differs at each type of institution. The top three factors for the sectarian alumnae are heavily concentrated in (1) knowledge of institutional mission, (2) loyalty to institution, and (3) making a positive impact with the gift. The public and private alumnae share two of the top three choices but not to the same degree. The public and private alumnae's choices are more diversified among all the factors. A number of factors do stand out and are worth special attention.

A sense of obligation was much more popular among the public and private alumnae. Some women indicated, in the "Comments" section of the survey, that they received financial aid in the form of scholarships and awards from their institution, and without that aid they would have been unable to attend. Others noted that they benefited from their education and they felt obligated to pay back. With this in mind, development offices should know which alumnae 
received financial aid. Specific marketing material could be developed to address this fact when soliciting gifts.

Making a positive impact with a gift was chosen by one half of all the alumnae in the study. This implies that marketing material should state clearly and concisely how alumnae gifts are being used and why it is so important to the institution. Publications should include a letter from the president to alumna and articles that specifically address areas of interest and concern of all alumnae.

Loyalty to the institution was very popular among the sectarian and private alumnae. The question that fund raisers should be asking is: how does an institution instill a sense of loyalty? Loyalty evolves over time; therefore it is a characteristic that must be nurtured when students first begin their college education. For a feeling of loyalty to develop, students must feel connected to the institution and believe in its mission. This can be a daunting task for large institutions such as the two universities in this study; therefore specific schools and departments within the institution must take on this responsibility. Programs should be developed to create a feeling of connectivity (e.g., mentorship, faculty/ student research projects, etc.).

The mission of the institution was the first choice of the sectarian alumnae. This may be due to the sectarian nature and the small size of the institution. The sectarian institution serves a very specific niche, where the mission of the institution is used to attract its clientele. All institutions need a clear and concise mission statement. However, the results of this study suggest that alumnae of small private sectarian institutions may place a higher emphasis on this characteristic than public or private nonsectarian institutions.

One last factor worth mentioning is the tax benefits of a gift. Although it was chosen by only just over 20 percent of the public and private alumnae and only 10 percent of the sectarian alumnae, it should be included in the marketing material. If presented properly, the amount of the gift may be increased due to favorable tax treatment.

Table 2 presented the areas that alumnae are most likely to support financially. Factors that persuade women to give may also influence the programs and areas they are most likely to support. Scholarships, awards, and loans were very important to alumnae from all three institutions. As mentioned previously, this may be due to the sense of obligation felt by many alumnae. Therefore, it is not surprising that this area is highly supported. With rising tuition, the demands on this area of support will continue to grow. Again, fund raisers should target alumnae who received institutional aid during their college years. This would offer the alumna an opportunity to repay the institution by supporting a current student who faces the same financial challenges as she did while attending college. Personalizing the scholarship and award program in this manner may strengthen the alumna's sense of obligation. If possible, scholarship recipients should know who the donors are and personally thank them for their gift, which may enhance the donor's satisfaction with regard to the positive impact of the gift.

The general fund is the least restrictive area for the institution in terms of financial allocation. Although institutions are free to spend money where they 
choose, they take on a greater responsibility of stewardship. It would be to the institutions' benefit to have a clear and concise plan for the general fund. This will make it easier to raise necessary funds, while keeping financial control within the institution. The general fund was the area most supported by the sectarian alumnae. It would be interesting to discover if this is due to the institutional size, type, and/or a well developed and communicated spending plan for the general fund.

A specific school/department was an important area of support at both the public and private institutions. Both these schools are large universities with many areas of study, whereas the sectarian institution is a small liberal arts college. This implies that alumnae at larger institutions are more connected to specific schools or departments compared with the institution as a whole. With this in mind, schools/departments must nurture this support by developing a sense of connectivity, thereby creating a sense of loyalty.

Almost half of the sectarian alumnae supported renovations and new building, which was considerably more than the other institutions. At the time of the study the sectarian institution was conducting a capital campaign, which included raising funds for a new building. This may have influenced the interest in this particular area.

\section{Study Limitations}

The study was limited, based on the population and the institutions sampled. Further research should be conducted in other geographical locations, which may yield different outcomes based on local beliefs and/or cultural differences. Other institutions such as single gender or historically black colleges and universities may also experience different outcomes.

\section{Conclusion}

As fund raising continues to grow in the higher education arena, college and university administrators and faculty must explore every opportunity to raise needed funding for the next generation of students. Women are an important and growing part of this complex equation. The job of the institution is to continually refine the message being sent to alumnae with specific marketing campaigns that blend the wishes of the donor with the needs of the institution.

\section{References}

1. "Women philanthropists support change" (1995), Women in Higher Education 4, 10, pp. 8-9.

2. United States Department of Education (2002), National Center for Education Statistics, Integrated Postsecondary Education Data System, Total Fall Enrollment survey 1947 to 1999, Department of Education, Washington, DC, Table 172.

3. S. C. Shaw and M. A. Taylor (1995), Reinventing Fundraising: Realizing the Potential of Women's Philanthropy, Jossey-Bass, San Francisco, p. 7.

4. Ibid.

5. UCLA Women and Philanthropy (1992), Executive Summary, available at http:// women.support.ucla.edu/executive.htm; A. R. Kaminski and M. A. Taylor (1998) "What motivates women to give? A recent survey reveals the answerand more," Association of Healthcare Philanthropy Journal, Spring; A. Radley and M. Kennedy (1995), "Charitable giving by individuals," Human Relations, 48, 6, pp. 685-709.

6. UCLA Women and Philanthropy (1992), Executive Summary, op. cit.

7. Radley and Kennedy (1995), "Charitable giving by individuals"; Kaminski and Taylor (1998), "What motivates women to give?", p. 8.

8. R. M. Simari (1995), "Philanthropy and higher education: Women as donors," Doctoral dissertation, Hofstra University, p.8.

9. D. E. Bressi, D. E. (1999), "Women and philanthropy: Making a difference in higher education," Doctoral dissertation, The University of Tennessee. 
10. C. S. Fisher, C. S. Tidball, \& M. E. Tidball (2000), "Women and philanthropy," Council for the Advancement and Support of Education (CASE), Washington, D C/ Tidball Center for the Study of Educational Environments, Hood College, Frederick, MD, p.3.

11. Bressi (1999), "Women and philanthropy" op. cit.; Fisher et al. (2000), "Women and philanthropy" op. cit.; J. M. Shim (2001), "Relationship of selected alumnae characteristics to alumnae financial support at a women's college," Doctoral dissertation, University of Florida; Simari (1995), "Philanthropy and higher education," op. cit.

12. Simari (1995), "Philanthropy and higher education," op. cit. p. 155.

13. D. A. Dillman (1978), Mail and Telephone Surveys: The Total Design Method, John Wiley, New York.

\section{Practitioner's Perspective}

Dr. Briechle offers an interesting and valuable addition to the growing body of research about the giving patterns of women. He is correct in pointing out that women control an increasing percentage of the potential philanthropic dollar, and that understanding giving patterns from women is a significant lesson for development professionals. Women are an important constituency and growing more important all the time. Both because women tend to live longer and, therefore, often control the final distribution of family wealth, and because women are increasingly entrepreneurs and professionals who control their own resources all along, colleges and universities of all types need to look seriously at women's patterns of giving. Even as we acknowledge this fact, we should, however, also recognize that women give for many reasons and that women's motivations for giving are no more monolithic than they are for men.

Dr. Briechle asks a key question about institutional type and seeks to investigate whether there are any differences in motivation or focus from different kinds of institutions. This work complements the Fisher et al. (2000) study sponsored by CASE several years ago, which studied the motivations and giving patterns of graduates from historically women's colleges versus those from historic coeducational institutions. That study demonstrated that women tend to give more to institutions with which they were personally involved and that volunteer activity was highly correlated with increased giving, as issue which future research might explore even further.

There are a series of valuable and practical suggestions to development professionals to be found in this study. The desire to "give back" is clearly one of the most important of these. Connecting donors who received scholarships as students with scholarship recipients is one specific suggestion that many practitioners could implement with, as this study suggests, potential positive results. As the study also points out, women (and, one might well argue, men also) are increasingly concerned to know the impact of their gifts. Demonstrating the specific way in which a gift has changed the institution is often the best way of generating a comfort level for the donor and, therefore, a basis for the next (and, one would hope, even larger) gift.

This study builds a good foundation for even further research and discussion, as all of us in the profession seek to refine our approach to each of our significant donor groups. Comparative studies, looking at women's motivations side by side 
with those of men from the same institutions, will give an even better set of guidelines for future initiatives. Likewise, it would be valuable to know more about the influence of institutional size on donor motivations. Although the author points out differences between the small sectarian institution and the large private and public institutions, it is unclear how much of the difference is because of the small size or the sectarian nature of his third institution. The study would have given us more specific and statistically valid information had he used three large institutions and three small institutions, each with a public, private nonsectarian, and private sectarian character. It would also have been valuable had either all of these institutions or none of his institutions been involved in a capital campaign. I suspect that some of his data were skewed by the fact that the small sectarian institution was in a capital campaign and others were not.

Finally, the author makes a passing reference to the potential impact of tax benefits on the size of a gift. Some of the work sponsored by the National Committee on Planned Giving would indicate a strong correlation between tax benefits and gift size. Although this question is beyond the scope of this study, it is also one that is much on the minds of practitioners. We are always interested in what motivates people to give, but we are even more interested in how to turn a relatively small gift into a much larger one. Future research may help to gain an even better handle on this question.

Dr. Briechle adds to our body of knowledge and provides a model for other researchers. Through an expansion and modification of research methodology, we might learn even more about the motivational and giving patterns of our women graduates. 